\title{
ANTIBACTERIAL ACTIVITY OF PROPOLIS PRODUCED BY Frieseomelitta varia
}

\author{
Atividade antibacteriana da própolis produzida por Frieseomelitta varia
}

\author{
Viviane Aparecida Costa Campos ${ }^{1}$, Helvécio Martins dos Santos Júnior ${ }^{1}$, Denilson F. Oliveira ${ }^{2}$, \\ Hudson Walace Pereira de Carvalho ${ }^{1}$, Alan Rodrigues Teixeira Machado ${ }^{1}$, Aline Auxiliadora Tirelli ${ }^{1}$
}

\begin{abstract}
To contribute to the development of antibacterial products from propolis produced by native Brazilian bees, twenty-nine samples of propolis collected from hives in the state of Minas Gerais, Brazil, were screened for in vitro activity against Aeromonas hydrophila, Bacillus subtilis, Pseudomonas aeruginosa, and Staphylococcus aureus. Among the samples from native Brazilian bees, only that from Frieseomelitta varia (Lepeletier, 1836) inhibited in vitro bacterial growth. Consequently, this propolis underwent fractionation by chromatographic methods monitored through Agar-diffusion assays with these bacteria, which resulted in the isolation and identification of 3,5-diprenyl-4-hydroxycinnamic acid (artepillin C), which showed MIC of 62.5 and $250 \mu \mathrm{g} / \mathrm{mL}$ against B. subtilis and $S$. aureus, respectively. This result indicates the potential of $F$. varia to produce therapeutic propolis.
\end{abstract}

Index terms: Artepillin C, stingless bees, antibiotic.

\section{RESUMO}

Para contribuir para o desenvolvimento de produtos antibacterianos obtidos de própolis produzidos por abelhas nativas do Brasil, 29 tipos de própolis coletados de diferentes colméias no Estado de Minas Gerais, Brasil, foram avaliados quanto à atividade in vitro contra Aeromonas hydrophila, Bacillus subtilis, Pseudomonas aeruginosa, e Staphylococcus aureus. Dentre as amostras de abelhas nativas, somente a de Frieseomelitta varia (Lepeletier, 1836) inibiu, em teste in vitro, o crescimento bacteriano. Consequentemente, essa própolis foi submetida a métodos cromatográficos para o fracionamento biomonitorado por teste de difusão em Agar com as referidas bactérias, o que resultou no isolamento e identificação do ácido 3,5-diprenil-4-hidroxicinâmico (artepelin C), que apresentou CIM de 62,5 e $250 \mu \mathrm{g} / \mathrm{mL}$ frente a $B$. subtilis e $S$. aureus, respectivamente. Esses resultados indicam o potencial de F. varia para a produção de própolis terapêutica.

Termo para indexação: Artepelin C, abelhas sem ferrão, antibiótico.

(Received in may 5, 2011 and approved in june 27, 2011)

\section{INTRODUCTION}

The combination of plant exudates, pollen, bee salivary secretions, and beeswax, results in a resinous material known as propolis, the main purpose of which is apparently to protect the beehive against microorganisms (MARCUCCI, 1995; GHISALBERTI, 1979; TORRES et al., 2008). This complex mixture has been used in folk medicine since antiquity, and several biological activities, including antibacterial (PETROVA et al., 2010; KALOGEROPOULOS et al., 2009), antiviral (DIAZ-CARBALLO et al., 2010), fungicidal (DOTTA et al., 2011; KALOGEROPOULOS et al., 2009), cytotoxic (VALENTE et al., 2011), anti-inflammatory (CALDERÓNMONTANO et al., 2011), immunomodulator (ORSATTI et al., 2010ab), antioxidant (VALENTE et al., 2011; KALOGEROPOULOS et al., 2009), and antitumor
(VALENTE, et al., 2011), have been confirmed for propolis obtained from sources around the world.

The chemical composition of propolis depends upon the abundance and diversity of plant species visited by bees in the region of its production (CUSTÓDIO et al., 2003). More than 300 substances have been identified in samples of propolis from different regions (PEREIRA et al., 2002). Classes of compounds commonly found in propolis include flavonoids (PETROVA et al., 2010), prenylated flavanones (EL-BASSUONY, 2009), benzopyranes (SILICI et al., 2007), benzophenones (ISHIDA et al., 2011), caffeic acid esters (CAO et al., 2011), triterpenoids (PEREZ et al., 2009), benzoic acid (XU et al., 2010) and cinnamic acid derivatives (YANG, 2011), and naphthoquinone epoxides (TRUSHEVA et al., 2006).

1Universidade Federal de Lavras/UFLA - Lavras - MG - Brasil

2Universidade Federal de Lavras/UFLA - Departamento de Química/DQI - Laboratório de Produtos Naturais - Campus Universitário - Cx. P. 3037 37200-000 - Lavras - MG - Brasil - denilson@dqi.ufla.br 
Brazil is the second-largest producer of propolis worldwide, after China (LUSTOSA et al., 2008). Although more than 400 species of native bees have been identified in Brazil, Apis mellifera (Linnaeus, 1758), which was introduced in Brazil by Europeans, is used almost exclusively by Brazilian beekeepers to produce propolis (KERR et al., 1996; MENEZES et al., 2007). Consequently, few reports are found in the literature on the products of native Brazilian bees, which have potential for the production of high-quality honey and propolis (BANKOVA et al., 1999). Therefore, the general aim of the present study was to contribute to the development of propolis produced by native Brazilian bees as a natural antibacterial agent. Initially, the antibacterial activities of propolis produced by seven native bee species and A. mellifera were evaluated and compared. Then, the propolis produced by Frieseomelitta varia (Lepeletier, 1836) underwent a bioassay-guided fractionation to identify the antibacterial component. The bioassays were carried out with Gram-negative (Aeromonas hydrophila and Pseudomonas aeruginosa) and Gram-positive (Bacillus subtilis and Staphylococcus aureus) bacteria commonly used to assess the antibacterial activity of samples through the agar diffusion assay (NCCLS, 2009; HSOUNA et al., 2011; GONÇALVES et al., 2011).

\section{MATERIAL AND METHODS}

\section{Propolis}

Samples were collected in the state of Minas Gerais, Brazil, in 2005, and the corresponding insects were deposited in the Regional Museum of Entomology of the Federal University of Viçosa (Table 1). Adapting the method described in the literature (NCCLS, 2009), an aliquot $(25 \mathrm{mg})$ of each sample was dissolved in $2.5 \mathrm{~mL}$ of

Table 1 - Propolis collected from hives of different species of bees in the state of Minas Gerais, Brazil, during the year 2005.

\begin{tabular}{|c|c|c|c|c|c|}
\hline Code No. & Scientific name & Vernacular name & $\begin{array}{c}\text { Date } \\
(\mathrm{dd} / \mathrm{mm})\end{array}$ & City & $\begin{array}{l}\text { Number of } \\
\text { hives }\end{array}$ \\
\hline 1 to 5 & $\begin{array}{l}\text { Apis mellifera (Linnaeus, } \\
1758 \text { ) }\end{array}$ & European honey bee & $23 / 03$ & $\begin{array}{l}\text { São João del } \\
\text { Rei }\end{array}$ & 5 \\
\hline 6 to 8 & A. mellifera & European honey bee & $11 / 04$ & Lavras & 3 \\
\hline 9 & A. mellifera & European honey bee & $25 / 04$ & Lavras & 1 \\
\hline 10 & $\begin{array}{l}\text { Friesella schrottkyi } \\
\text { (Friese, 1900) }\end{array}$ & Mirin preguiça & $15 / 08$ & Viçosa & 1 \\
\hline 11 to 13 & $\begin{array}{l}\text { Frieseomelitta varia } \\
\text { (Lepeletier, 1836) }\end{array}$ & Marmelada/Moça branca & $15 / 08$ & Viçosa & 3 \\
\hline 14 & F. varia & Marmelada/Moça branca & $15 / 08$ & Viçosa & 1 \\
\hline 15 & F. varia & Marmelada/Moça branca & $14 / 02$ & Lavras & 1 \\
\hline 16 & $\begin{array}{l}\text { Melipona bicolor } \\
\text { (Lepeletier, 1836) }\end{array}$ & Pé-de-pau & $15 / 08$ & Viçosa & 1 \\
\hline 17 & M. bicolor & Pé-de-pau & $15 / 08$ & Viçosa & 1 \\
\hline 18 to 19 & M. bicolor & Pé-de-pau & $15 / 08$ & Viçosa & 2 \\
\hline 20 & M. bicolor & Pé-de-pau & $15 / 08$ & Viçosa & 1 \\
\hline 21 & $\begin{array}{l}\text { Melipona quadrifasciata } \\
\text { (Lepeletier, 1836) }\end{array}$ & Mandaçaia & $15 / 08$ & Viçosa & 1 \\
\hline 22 & $\begin{array}{l}\text { Nannotrigona testaceicornis } \\
\text { (Lepeletier, 1836) }\end{array}$ & Iraí & $15 / 08$ & Viçosa & 1 \\
\hline 23 to 24 & $\begin{array}{l}\text { Plebeia droryana } \\
\text { (Friese, 1900) }\end{array}$ & Mirin & $15 / 08$ & Viçosa & 2 \\
\hline 25 & P. droryana & Mirin & $15 / 08$ & Lavras & 1 \\
\hline 26 & $\begin{array}{l}\text { Tetragonisca angustula } \\
\text { (Latreille, 1811) }\end{array}$ & Jataí & $19 / 01$ & Lavras & 1 \\
\hline 27 & T. angustula & Jataí & $15 / 08$ & Viçosa & 1 \\
\hline 28 & T. angustula & Jataí & $15 / 08$ & Viçosa & 1 \\
\hline 29 & T. angustula & Jataí & $15 / 08$ & Viçosa & 1 \\
\hline
\end{tabular}

Agar-diffusion assay.

Ciênc. agrotec., Lavras, v. 35, n. 6, p. 1043-1049, nov./dez., 2011 
chloroform to give a solution $(10 \mathrm{mg} / \mathrm{mL})$ from which $300 \mu \mathrm{L}$ were withdrawn to impregnate $6.0 \mathrm{~mm}$-diameter paper disks (Cefar Diagnóstica, Brazil) with samples to be evaluated. After 20 min under a gentle flow of air to remove the solvent, the disks were employed in the agar-diffusion assay.

Experiments were adapted from the literature (BELAQZIZ, et al., 2010: OZTÜRK; MERIC, 2011). Briefly, the Gram-negative bacteria Aeromonas hydrophila ATCC 7966 and Pseudomonas aeruginosa ATCC 27853 and the Gram-positive bacteria Bacillus subtilis ATCC 6633 and Staphylococcus aureus ATCC 25923, maintained at $-70^{\circ} \mathrm{C}$, were cultivated in tryptic-Soy-agar (TSA, Acumédia) at $37^{\circ} \mathrm{C}$ for $48 \mathrm{~h}$. Then, the bacteria were transferred to glass tubes containing an aqueous $0.85 \%(\mathrm{~g} / \mathrm{mL}) \mathrm{NaCl}$ solution. Their concentrations were calibrated in accordance with the Mc Farlad scale (0.5 for A. hydrophila, P. aeruginosa, and $S$. aureus, and $1.0 \mathrm{~B}$. subtilis). Bacteria were transferred from these suspensions with a Swab to Mueller-Hinton-agar culture medium (Himedia, India) contained in $90 \mathrm{~mm}$ Petri dishes and paper disks impregnated with a sample as described above were then applied to the surface of the culture medium. After incubation for $24 \mathrm{~h}$ at $37^{\circ} \mathrm{C}$, inhibition-zone diameters were measured. The experiments were carried out in triplicate. Paper disks treated with chloroform and impregnated with $10 \mu \mathrm{g}$ of norfloxacin (Sensifar, Brazil) were used as negative and positive controls, respectively, in all experiments.

\section{Purification and identification of the antibacterial substance}

Propolis (Code 14, Table 1, $18.0 \mathrm{~g}$ ) from $F$. varia was added to a solution of chloroform/hexane $(1: 2,900 \mathrm{~mL})$. Insoluble materials were removed from the resulting mixture by filtration through a cotton-wool plug. The filtrate was concentrated to dryness in vacuo to yield $11.6 \mathrm{~g}$ of a yellow residue, which was fractionated on a column of silica gel (Merck, 0.040-0.063 mm, $60 \AA$ ) employing hexane with increasing concentrations of ethyl acetate as the mobile phase. Fractions with similar chemical compositions were combined after thin-layer chromatography analyses to yield eight fractions (F1 to F8). Aliquots of each fraction (3.0 mg) and the abovementioned yellow residue $(30 \mathrm{mg})$ were added to 6.0 mm-diameter paper disks (Cefar Diagnóstica, Brazil) and screened for activity in the agar-diffusion assay. F4 $(1.174 \mathrm{~g})$ was further fractionated by silica-gel chromatography, using ethyl acetate/hexane/acetic acid (1:9:1) as the mobile phase. Aliquots $(0.7 \%)$ of the seven fractions (F9 to $\mathrm{F} 15)$ resulting from this procedure were also submitted to the agar-diffusion assay. Active fractions F10 (547.8 mg) and F11 (258.9 mg) were dissolved in solvent, and the resulting solutions were combined and concentrated to dryness. This resulted in a brown residue, which underwent fractionation on a high performance liquid chromatography (HPLC) system equipped with a diode array detector and a Gemini ${ }^{\circledR}$ C-18 semi-preparative column $(5 \mu \mathrm{m}, 250 \times 21.2 \mathrm{~mm}$; Phenomenex), using a methanol/water (75:25) solution containing $0.1 \%(\mathrm{v} / \mathrm{v})$ acetic acid as the mobile phase. Aliquots $(0.08 \%)$ of the four resulting fractions (F16 to F19) were tested in the agar-diffusion assay. Fraction F19 was further fractionated by HPLC using an acetonitrile/water (60:40) solution containing $0.1 \%$ (v/v) acetic acid as the mobile phase, to yield $27 \mathrm{mg}$ of a white powder, which was confirmed to be artepillin C (Figure 1) after spectrometric analyses. For mass spectrometric (MS) analysis, $20 \mu \mathrm{L}$ of a solution of artepillin C $(0.5 \mathrm{mg})$ in water/methanol $(1: 1,1.0 \mathrm{~mL})$ was directly infused into the electrospray interface of an Agilent $1100^{\circledR} \mathrm{LC} / \mathrm{MS}$ Trap apparatus. Artepillin $\mathrm{C}$ was dissolved in deuterated methanol $\left(\mathrm{CD}_{3} \mathrm{OD}\right)$ and chloroform $\left(\mathrm{CDCl}_{3}\right)$ for nuclear magnetic resonance (NMR) analyses, which were performed on a Varian INOVA ${ }^{\circledR} 500\left({ }^{1} \mathrm{H}\right.$ NMR: $500 \mathrm{MHz}$ and ${ }^{13} \mathrm{C}$ NMR: $\left.125 \mathrm{MHz}\right)$ and a Bruker DRX ${ }^{\circledR} 400\left({ }^{1} \mathrm{H}\right.$ NMR: $400 \mathrm{MHz}$ ) spectrometer, respectively. Solvent peaks were employed as references, and twodimensional NMR techniques (COSY, HMQC, HMBC, and NOESY) were performed using standard Varian programs.

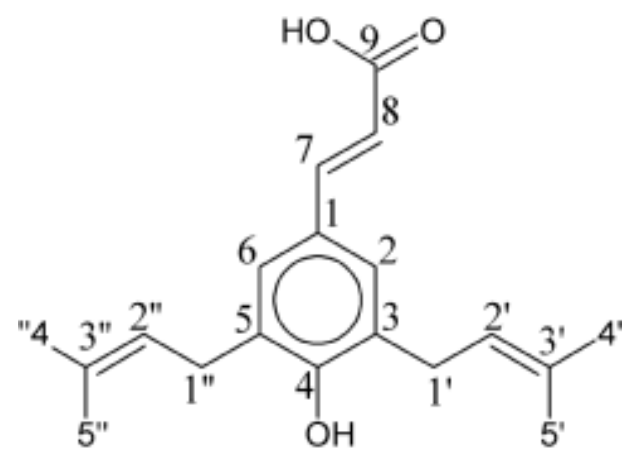

Figure 1 - Structure of artepillin C.

\section{Twofold serial microdilution assay}

Minimal inhibitory and minimal bactericidal concentrations (MIC and MBC) were determined by a 
broth micro dilution assay (NCCLS, 2003) using a 96well polypropylene plate and Mueller-Hinton broth (MHB: Biolife, Italy) supplemented with calcium and magnesium cations (ALDERMAN; SMITH, 2001). Artepillin C (2.0 mg) isolated as described above was dissolved in dimethyl sulfoxide (DMSO) $(100 \mu \mathrm{L})$, and the resulting solution was diluted to $1.0 \mathrm{~mL}$ with supplemented MHB. Suspensions $(5 \mu \mathrm{L})$ in supplemented MHB of the same bacteria employed in the agar-diffusion assay described above, at $7.5 \times 10^{-4}$ colony-forming units (CFU)/mL, were poured into each well. The total volume of liquid in each well was adjusted to $0.2 \mathrm{~mL}$ by the addition of artepillin $\mathrm{C}$ solution and the culture medium. After $24 \mathrm{~h}$ at $37^{\circ} \mathrm{C}$, a $10 \mu \mathrm{L}$ aliquot was removed from each well that displayed no bacterial growth, and these aliquots were subcultured in tryptic soy agar (Acumedia, USA) for $24 \mathrm{~h}$ at the same temperature. The MIC was considered to be the lowest concentration of the substance that prevented visible bacterial growth in the well, and the MBC was defined as the lowest concentration yielding negative subcultures for $24 \mathrm{~h}$. The experiment was carried out in triplicate using chloramphenicol (Sigma, USA) dissolved in DMSO and diluted with the culture medium as a control.

\section{RESULTS AND DISCUSSION}

All samples of propolis from A. mellifera hives showed antibacterial properties, but the magnitude of the activity varied according to the geographical location of the hive. Propolis samples 1 to 5 inhibited $S$. aureus growth, while samples 6 to 9 inhibited both $S$. aureus and B. subtilis (Table 2). This variation in the antibacterial activity is in accordance with results reported in the literature, and probably reflects the influence of the environment on the hive (STEPANOVIC et al., 2003; FERNANDES JÚNIOR et al., 2006). Most of the samples of propolis from Brazilian native bees were inactive, and only that from F. varia (code 14) inhibited bacterial growth. Both variations in the activity of propolis from A. Mellifera and F. varia suggest that the lack of antibacterial activity observed for samples from other native Brazilian bees may be reversed if propolis is collected from other hives or from the same hives in different seasons.

The fractionation of the propolis produced by $F$. varia (code 14), guided by agar-diffusion assays, resulted in a chromatographically pure white powder representing $0.3 \%(\mathrm{w} / \mathrm{w})$ of the propolis. More than one fraction with antibacterial properties was obtained during the process, suggesting that more than one active substance is produced by this bee. However, only the most active fraction in each stage was subsequently fractionated. The other fractions were stored for future studies.

The positive-ion mass spectrum of this powder displayed ions at $m / z 323[\mathrm{M}+\mathrm{Na}]^{+}$and $m / z 301[\mathrm{M}+\mathrm{H}]^{+}$, and collision-induced dissociation in helium on the latter ion resulted in a product ion at $\mathrm{m} / \mathrm{z} 283\left[\mathrm{M}+\mathrm{H}-\mathrm{H}_{2} \mathrm{O}\right]$. In negative-ion mode, a peak at $m / z 299$ [M-H] ${ }^{-}$was detected, which gave a product ion at $m / z 255\left[\mathrm{M}-\mathrm{H}-\mathrm{CO}_{2}\right]$. These results suggested a carboxylic acid with a molecular weight of $300 \mathrm{u}$ (SILVERSTEIN et al., 2005).

One- and two-dimensional NMR analyses carried out in $\mathrm{CD}_{3} \mathrm{OD}$ confirmed this result, since the data obtained were consistent with the structure of 3,5diprenyl-4-hydroxycinnamic acid, also known as artepillin C (Figure 1): ${ }^{1} \mathrm{HNMR}\left(500 \mathrm{MHz}, \mathrm{CD}_{3} \mathrm{OD}\right): \delta 7.14$ $(1 \mathrm{H}, \mathrm{s}, \mathrm{H}-2), 7.53$ (1H, d, J=16.0 Hz, H-7), $6.19(1 \mathrm{H}, \mathrm{d}$, $\mathrm{J}=16.0 \mathrm{~Hz}, \mathrm{H}-8), 3.32$ (2H, br.d, J=7.3 Hz, H-1' and 1', ), 5.32 ( $2 \mathrm{H}$, br.t, J=7.3 Hz, H-2' and 2' '), 1.76 (2H, s, H-4' and 4"), 1.72 (2H, s, H-5' and 5" ). ${ }^{13} \mathrm{C} \mathrm{NMR} \mathrm{(125} \mathrm{MHz,}$ $\left.\mathrm{CD}_{3} \mathrm{OD}\right): \delta 127.5$ (C-1), 128.4 (C-2 and 6), 130.2 (C-3 and 5), 156.3 (C-4), 147.2 (C-7), 115.4 (C-8), 171.2 (C-9), 29.5 (C-1' and 1"), 123.3 (C-2' and 2"), 134.0 (C-3' and 3"), 25.9 (C-4' and 4'), 17.9 (C-5' and 5'). Since no NMR spectrum of artepillin $\mathrm{C}$ dissolved in $\mathrm{CD}_{3} \mathrm{OD}$ was found in the literature, ${ }^{1} \mathrm{H} \mathrm{NMR}(400 \mathrm{MHz})$ analysis was also carried out in $\mathrm{CDCl}_{3}$ and the spectrum obtained was in complete agreement with data given in the literature (AGA et al., 1994; PARK et al., 2004).

The antibacterial properties of artepillin $\mathrm{C}$ were confirmed by a twofold serial microdilution assay (Table 3 ). Despite the low activity toward A. hydrophila, this substance was more efficient than the commercial antibacterial substance chloramphenicol against $B$. subtilis and $P$. aeruginosa. The results obtained so far are in agreement with previous reports, since artepillin $\mathrm{C}$ has previously been identified as one of the antimicrobial substances present in the propolis of A. mellifera (CASTRO et al., 2007). Additionally, artepillin C has proven antitumor (AGA et al., 1999; ORSOLIC et al., 2006) and immunomodulator(GEKKER et al., 2005) activities, which makes the propolis from $F$. varia very promising for pharmacological uses. 
Table 2 - Bacterial inhibition-zone diameter ( $\mathrm{mm}$ ) caused by $6.0 \mathrm{~mm}$-diameter paper disks impregnated with $3.0 \mathrm{mg}$ of propolis ( $300 \mu \mathrm{L}$ of a $10 \mathrm{mg} / \mathrm{mL}$ propolis solution) from Apis mellifera and Frieseomelitta varia in the agar-diffusion assay.

\begin{tabular}{ccccc}
\hline \multirow{2}{*}{ Code No. } & Source of propolis & \multicolumn{3}{c}{ Bacterial strains $^{\mathrm{a}}$} \\
\cline { 3 - 5 } & Apis mellifera & A. hydrophila & B. subtilis & S. aureus \\
\hline 1 & Apis mellifera & - & - & $10.0 \pm 1.0$ \\
3 & Apis mellifera & - & - & $15.0 \pm 2.0$ \\
4 & Apis mellifera & - & - & $14.0 \pm 2.0$ \\
5 & Apis mellifera & - & - & $12.0 \pm 1.0$ \\
6 & Apis mellifera & - & $11.0 \pm 2.0$ & $12.0 \pm 2.0$ \\
7 & Apis mellifera & - & $10.5 \pm 1.0$ & $12.0 \pm 3.0$ \\
8 & Apis mellifera & - & $10.0 \pm 1.0$ & $11.0 \pm 2.0$ \\
9 & Apis mellifera & - & $10.5 \pm 2.0$ & $10.5 \pm 1.0$ \\
14 & Frieseomelitta varia & $9.0 \pm 1.0$ & $7.5 \pm 1.0$ & $8.0 \pm 1.0$ \\
Chloroform & - & - & - & - \\
Norfloxacin & $36 \pm 3.0$ & $30 \pm 3.0$ & $29 \pm 3.0$ & $28 \pm 3.0$ \\
\hline
\end{tabular}

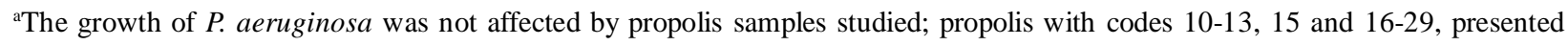
no antibacterial effect.

Table 3 - Minimal inhibitory (MIC) and minimal bactericidal concentration (MBC) of artepillin C and chloramphenicol against four bacteria.

\begin{tabular}{lcccccccc}
\hline \multirow{2}{*}{ Substance } & \multicolumn{2}{c}{ A. hydrophila } & \multicolumn{2}{c}{ B. subtilis } & \multicolumn{2}{c}{ P. aeruginosa } & \multicolumn{2}{c}{ S. aureus } \\
\cline { 2 - 8 } & MIC $^{\mathrm{a}}$ & MBC $^{\mathrm{a}}$ & MIC & MBC & MIC & MBC & MIC & MBC \\
\hline Artepillin C & $>1000$ & - & 62.5 & 62.5 & 500 & 500 & 250 & 250 \\
Chloramphenicol & 23.75 & - & 95 & - & $>500$ & - & 190 & - \\
\hline
\end{tabular}

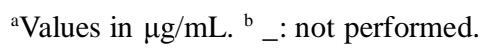

\section{CONCLUSION}

Concluding, the propolis produced by $F$. varia is potentially useful for the development of therapeutic products aimed to control bacterial diseases, since it showed in vitro antibacterial activity against $A$. hydrophila B. subtilis, $P$. aeruginosa, and $S$. aureus. This property was attributed to the substance artepillin $C$, which presented MIC values smaller than some of those observed for the commercial antibiotic chloranphenicol.

\section{ACKNOWLEDGMENTS}

The authors gratefully acknowledge CAPES (Coordenadoria de Aperfeiçoamento de Pessoal de Nível Superior) and FAPEMIG (Fundação de Amparo à Pesquisa do Estado de Minas Gerais) for financial support, and thank the Brazilian Biosciences National Laboratory (LNBio/ CNPEM) and CNRMN (Centro Nacional de Ressonância
Magnética Nuclear-Universidade Federal do Rio de Janeiro) for access to the NMR facilities.

\section{REFERENCES}

AGA, H.; et al. Propolis extract with improved watersolubility. Patent number 5922324. 1999.

AGA, H. et al. Isolation and identification of antimicrobial compounds in Brazilian propolis.

Bioscience, Biotechnology and Biochemistry, Tokyo, v.58, n.5, p.945-946, mai. 1994.

ALDERMAN, D.J. SMITH, P. Development of draft protocols of standard reference methods for antimicrobial agent susceptibility testing of bacteria associated with fish diseases. Aquaculture, Texas, v.196, n.3-4, p. 211-243, mai.2001. 
BANKOVA, V. et al. Phytochemical evidence for the plant origin of Brazilian propolis from São Paulo State. Zeitschrift für Naturforschung C, Mainz, v.54, n.5-6, p.401-405, mai./jun.1999.

BANSKOTA, A.H. et al. Chemical constituents of Brazilian propolis and their cytotoxic activities. Journal of Natural Products, Washington, v.61, n.7, p.896-900, jul.1998.

BELAQZIZ, R. et al. Antimicrobial and insecticidal activities of the endemic Thymus Broussonetii Boiss. and Thymus maroccanus Ball. Records of Natural Products, Ýstanbul, v4, n.4, p.230-237, abr.2010.

CALDERÓN-MONTAÑO, J.M. et al. A Review on the Dietary Flavonoid Kaempferol. Mini Reviews in Medicinal Chemistry, Oak Park, v.11, n.4, p. 298-344, apr., 2011.

CAO, W. et al. LC with electrochemical detection for analysis of caffeic acid and caffeic acid phenyl ester in propolis. Chromatographia, New York, v.73, n.3-4, p.411-414, feb., 2011.

CASTRO, M.L. et al. Própolis do sudeste e nordeste do Brasil: influência da sazonalidade na atividade antibacteriana e composição fenólica. Química Nova, São Paulo, v.30, n.7, p.1512-1516, out.2007.

CUSTODIO, AR.; et al. Clustering of comb and propolis waxes based on the distribution of aliphatic constituents. Journal of Brazilian Chemical Society, Campinas, v.14, n.3, p.354-357, mai/jun.2003.

DÍAZ-CARBALLO, D. et al. Antiretroviral activity of two polyisoprenylated acylphloroglucinols, 7-epinemorosone and plukenetione $\mathrm{A}$, isolated from Caribbean propolis. International Journal of Clinical Pharmacology and Therapeutics, Rockledge, v.48, n.10, p. 670-677, oct., 2010.

DOTA, K.F. et al. Antifungal activity of Brazilian propolis microparticles against yeasts isolated from Vulvovaginal candidiasis. Evidence-Based Complementary and Alternative Medicine, Oxford, v.2011, n.1, p.1-8, mar., 2011.

EL-BASSUONY, A.A. New prenylated compound from Egyptian propolis with antimicrobial activity. Revista
Latinoamericana de Quimica, México, v.37, n.1, p.85-90, apr., 2009.

FERNANDES JÚNIOR, A. et al. Atividade antimicrobiana de própolis de Apis mellifera obtidas em três regiões do Brasil. Ciência Rural, Santa Maria, v.36, n.1, 294-297, jan./fev.2006.

GEKKER, G. et. al. Anti-HIV-1 activity of propolis in CD4(+) lymphocyte and microglial cell cultures. Journal of Ethnopharmacology, Amsterdam, v.102, n.2, p.158-163, jul.2005.

GHISALBERTI, E.L. Propolis: a review. Bee World, Cardiff, v.60, n.2, p.59-84, jun.1979.

GONÇALVES, O. et al. Evaluation of the mutagenicity of sesquiterpenic compounds and their influence on the susceptibility towards antibiotics of two clinically relevant bacterial strains. Mutation Research/Genetic Toxicology and Environmental Mutagenesis, New York, v.723, n.1, p.18-25, jul., 2011.

HSOUNA, A.B. et al, Chemical composition, cytotoxicity effect and antimicrobial activity of Ceratonia siliqua essential oil with preservative effects against Listeria inoculated in minced beef meat. International Journal of Food Microbiology, New York, v.148, n.1, p.66-72, jul., 2011.

ISHIDA, V.F.C. et al. A new type of Brazilian propolis : Prenylated benzophenones in propolis from Amazon and effects against cariogenic bacteria. Food Chemistry, New York, v.125, n.3, p.966-972, apr., 2011.

KALOGEROPOULOS, N. et al. Chemical composition, antioxidant activity and antimicrobial properties of propolis extracts from Greece and Cyprus, Food Chemistry, New York, v.116, n.2, p.452-461, sep., 2009.

KERR, W.E.; CARVALHO, GA. NASCIMENTO, V.A. Abelha uruçu: biologia, manejo e conservação. Paracatu, Fundação Acangaú, 1996. 144p.

LUSTOSA, S.R. et al. Própolis: atualizações sobre a química e a farmacologia. Revista Brasileira de Farmacognosia, João Pessoa, v.18, n.3, p.447-454. jul./ set.2008.

MARCUCCI, M.C. Propolis: chemical composition, biological properties and therapeutic activity.

Apidologie, Les Ulis, v.26, n.2, p.83-99, mar./abr.1995. 
MENEZES, C. et al. Competição entre abelhas durante forrageamento em Schefflera arboricola. Bioscience Journal, Uberlândia, v.23, n.1, p.58-62, jan./mar.2007.

\section{NCCLS. Methods for dilution antimicrobial} susceptibility tests for bacteria that grow aerobically, Wayne, National Clinical and Laboratory Standards Institute, 2009. 65p.

ORSATTI, C.L. et al. Th1/Th2 cytokines' expression and production by propolis-treated mice. Journal of Ethnopharmacology, Amsterdam, v. 129, n.3, p.314-318, jun., 2010.

ORSATTI, C.L. et al. Propolis immunomodulatory action In vivo on toll-like receptors 2 and 4 expression and on pro-inû ammatory cytokines production in mice.

Phytotherapy Research, Malden, v.24, n.8, p.1141-1146, aug., 2010.

ORSOLIC, N.; SARANOVIC, A.B.; BASIC, I. Direct and indirect mechanism(s) of antitumour activity of propolis and its polyphenolic compounds. Planta Medica, New York, v.72, n.1, p.20-27, nov.2006.

ÖZTÜRK, H.; KOLAK, U.; MERIC, C. Antioxidant, anticholinesterase and antibacterial activities of Jurinea consanguinea DC. Records of Natural Products, Ýstanbul, v.5, n.1, p.43-51, jan.2011.

PARK, Y.K. et al. Chemical constituents in Baccharis dracunculifolia as the main botanical origin of southeastern Brazilian propolis. Journal of Agricultural and Food Chemistry, Washington, v.52, n.5, p.1100-1103, jan.2004.

PEREIRA, A,S.; SEIXAS, F.R.M.S.; AQUINONETO, F.R. Própolis: 100 anos de pesquisa e suas perspectivas futuras. Química Nova, SãoPaulo, v.25, n.2, p.321-326, mar.2002.

PEREZ, J.C.B.; BEST, C.R.; LLANES, F. Pentacyclic triterpenes in propolis. Revista de la Sociedad Quimica del Peru, Peru, v.75, n.4, p.439-452, oct., 2009.

PETROVA, A. et al. New biologically active compounds from Kenyan propolis. Fitoterapia, Rio de Janeiro, v.81, n.6, p.509-514, sep., 2010.

\section{SILICI, S.; UENLUE, M.; VARDAR-UENLUE, G}

Antibacterial activity and phytochemical evidence for the plant origin of Turkish propolis from different regions. World Journal of Microbiology \& Biotechnology, New York, v.23, n.12, p.1797-1803, dec., 2007.

SILVERSTEIN, R.M.; WEBSTER, F.X.; KIEMLE, D. Spectrometric Identification of Organic Compounds, 6.ed. Hoboken, John Wiley \& Sons, 2005. 502p.

STEPANOVIC, S. et al. In vitro antimicrobial activity of propolis and synergism between propolis and antimicrobial drugs. Microbiology Research, Pavia, v.158, n.4, p.353-357, nov.2003.

TORRES, R.N.S., et al. Constituintes voláteis de própolis piauiense. Química Nova, São Paulo, v.31, n.3, p.479485, mai.2008.

TRUSHEVA, B.; T. et al. Bioactive constituents of brazilian red propolis. Evidence-based complementary and alternative medicine, Cairo, v.3, n.2, p.249-254, may., 2006.

VALENTE, M.J. et al. Biological activities of Portuguese propolis: protection against free radicalinduced erythrocyte damage and inhibition of human renal cancer cell growth in vitro. Food and Chemical Toxicology, New York, v.49, n.1, p.86-92, jan., 2011.

XU, X. et al. Propolis essential oil extracted by different methods: chemical composition analysis and antibacterial activity evaluation. Chinese Academy of Agricultural Sciences, Beijing, v.31, n.3, p.60-63, jan., 2010.

YANG, H. et al. Antioxidant compounds from propolis collected in Anhui, China. Molecules, Shanghai, v.16, n.4, p.3444-3455, apr., 2011. 